Gut, 1969, 10, 185-193

\title{
Systemic sclerosis and small bowel involvement
}

\author{
RODNEY BLUESTONE, M. MACMAHON, AND J. M. DAWSON \\ From the Departments of Medicine and of Diagnostic Radiology, \\ Royal Postgraduate Medical School, London
}

Systemic sclerosis (scleroderma) is a generalized disease involving many organs (Tuffanelli and Winkelmann, 1961 ; Bianchi, Bistue, Wendt, Puro, and Keech, 1966; Rodnan, 1966) including the gastrointestinal tract. The oesophagus is particularly prone to involvement, sometimes producing severe dysphagia, and has been reported abnormal in up to $80 \%$ of patients with scleroderma examined by radiology and/or motility measurements (Treacy, Baggenstoss, Slocumb, and Code, 1963; Kemp-Harper and Jackson, 1965; Atkinson and Summerling, 1966; Niepel, Kostka, and Monca, 1966; Saladin, French, Zarafonetis, and Pollard, 1966; Clark and Fountain, 1967). Less attention has been paid to small bowel involvement; radiological abnormalities have been described by Hale and Schatzki (1944), Heinz, Steinberg, and Sackner (1963), Meszaros (1958), Sommerville, Bargen, and Pugh (1959), Reinhardt and Barry (1962), Kemp-Harper and Jackson (1965), and histological involvement has been recorded in the pathological studies made by Kraus (1924), by Goetz and Berne (1945), by Abrams, Carnes, and Eaton (1954), by Goldgraber and Kirsner (1957), by Rosenthal(1957), by Crown (1961), by Sackner (1966), and by Fountain and Nash (1967). Many individual cases of systemic sclerosis involving small bowel causing malabsorption or obstruction have been reported (Orabona and Albano, 1958; Herrington, 1959; Horswell, Hargrove, Peete, and Ruffin, 1961; Hoskins, Norris, Gottlieb, and Zamcheck, 1962; Leneman, Fierst, Gabriel, and Ingegno, 1962; Sonneveldt, Van Leeuwen, and Blom, 1962; McBrien and Lockhart-Mummery, 1963; Drake, LeFeber, and Patterson, 1964; Case reports, Mayo Clinic Proceedings 1965, and New England Journal of Medicine, 1965; Kahn, Jeffrie, and Sleisengers, 1965; Rossen and Yesner, 1965; Cliff, Herber, and Dennis, 1966; Salen, Goldstein, and Wirts, 1966; Greenberger, Ruppert, and Tzogournis, 1967), but these do not establish the incidence of small bowel involvement nor the relationship of structural changes to function.

We have studied the small bowel in 21 prospective patients with systemic sclerosis: 18 women aged 28 to 72 years (mean 53 years) and three men aged 60 to 71 years (mean 64 years). The duration of their systemic sclerosis ranged from six months to 20 years (mean 8.5 years). The overall disease was assessed as severe in six patients, moderately severe in nine, and mild in six. Small bowel structure was assessed by barium follow-through examination and in some cases by mucosal biopsy, and these changes were related to changes in small bowel function and the nutritional status of the patient. In addition, the relationship between small bowel involvement and other manifestations of the disease was examined.

\section{METHODS}

RADIOLOGICAL Barium meal and follow-through examinations were carried out using approximately 6 to $8 \mathrm{oz}$ Micropaque. Radiographs were assessed without knowledge of the clinical severity of the disease or the results of the tests of small bowel function. All deviations from normal were noted. The diameters of the lumen of the duodenum, jejunum, and ileum were measured (Fig. 1). The widest diameter of the duodenum was recorded. From a review of 50 random barium meals (Dawson, 1968) the upper limit of normal was taken to be $35 \mathrm{~mm}$. For the jejunum, a mean of the three widest diameters was recorded, the upper limit of normal being taken as $30 \mathrm{~mm}$ (Laws, Shawdon, Booth, and Stewart, 1963). For the ileum, an upper limit of $25 \mathrm{~mm}$ was accepted (Golden. 1965).

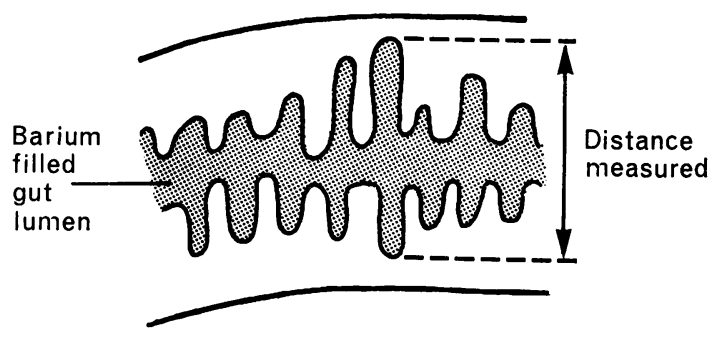

FIG. 1. Method of measuring bowel lumen diameter. 
HAEMATOLOGICAL AND BIOCHEMICAL Haematological techniques were used as described by Dacie and Lewis (1963).

Biochemical estimations were made according to Wootton (1964). Serum vitamin $B_{12}$ levels were estimated by microbiological assay using Eugena gracilis (Anderson, 1964); the normal range is 160 to $925 \mu \mu \mathrm{g} / \mathrm{ml}$. Serum folic acid levels were measured by microbiological assay using $L$ casei. Control subjects have levels of more than $6 \mathrm{~m} \mu \mathrm{g} / \mathrm{ml}$ (Waters and Mollins, 1961). Urinary excretion of Figlu after the ingestion of $15 \mathrm{~g}$ of histidine was measured by the method of Chanarin and Bennett (1962); normals do not excrete more than $17 \mathrm{mg}$. Urinary indican excretion was measured by the method of Curzon and Walsh (1962); the range of excretion by control subjects on an average hospital diet is 23 to $92 \mathrm{mg}$ per 24 hours. Vitamin $\mathbf{B}_{12}$ absorption was measured by the Schilling technique (1953); control subjects excrete more than $10 \%$ of the oral dose of $1 \mu \mathrm{g}$. Faecal fats were measured by the method of Van de Kamer (1949); the normal is less than $5 \mathrm{~g}$ per day. Intestinal mucosal biopsies were obtained either from the duodenum or from the jejunum using a Crosby capsule (Crosby and Kugler, 1957). Protein loss into the bowel was assessed in two patients using intra-

T A B L E I

CLINICAL FEATURES AND RESULTS OF INTESTINAL FUNCTION STUDIES IN 21 PATIENTS WITH SYSTEMIC SCLEROSIS

\begin{tabular}{|c|c|c|c|c|c|c|c|c|c|c|}
\hline \multirow[t]{2}{*}{ Patient } & \multirow[t]{2}{*}{ Sex } & \multirow[t]{2}{*}{ Age } & \multirow{2}{*}{$\begin{array}{l}\text { Duration of } \\
\text { Systemic } \\
\text { Sclerosis } \\
\text { (Years) }\end{array}$} & \multicolumn{3}{|l|}{ Clinical } & \multicolumn{4}{|l|}{ Nutrition } \\
\hline & & & & $\begin{array}{l}\text { Severity of } \\
\text { Systemic } \\
\text { Sclerosis }\end{array}$ & $\begin{array}{l}\text { Intestinal } \\
\text { Symptoms }\end{array}$ & $\begin{array}{l}\text { Radiological } \\
\text { Severity of } \\
\text { Bowel } \\
\text { Involvement }\end{array}$ & $\begin{array}{l}H b \\
(n=14 \cdot 0 \mathrm{gl} \\
100 \mathrm{ml})\end{array}$ & $\begin{array}{l}\text { Serum } \\
\text { Albumin } \\
(n=3- \\
5.5 \mathrm{~g} \\
1100 \mathrm{ml})\end{array}$ & $\begin{array}{l}\text { Serum } \\
\text { Folate } \\
(n=6-21 \\
m \mu g / m l)\end{array}$ & $\begin{array}{l}\text { Serum } \\
B_{12} \\
(n=>160 \\
\mu \mu g / m /)\end{array}$ \\
\hline 1 & $\mathbf{F}$ & 48 & 10 & Severe & $\begin{array}{l}\text { Constipation, } \\
\text { episode } \\
\text { of ileus }\end{array}$ & Severe & $12 \cdot 0$ & $4 \cdot 3$ & $7 \cdot 2$ & 960 \\
\hline 2 & $\mathbf{F}$ & 62 & 1 & Mild & None & Severe & $13 \cdot 0$ & $3 \cdot 0$ & $2 \cdot 9$ & 385 \\
\hline 3 & $\mathbf{F}$ & 33 & 16 & Severe & $\begin{array}{l}\text { Diarrhoea, } \\
\text { constipation }\end{array}$ & Severe & $12 \cdot 0$ & $3 \cdot 7$ & $2 \cdot 3$ & 285 \\
\hline 4 & $\mathbf{M}$ & 71 & 8 & Severe & Diarrhoea & Severe & $11 \cdot 0$ & $3 \cdot 2$ & $3 \cdot 2$ & 490 \\
\hline 5 & $\mathbf{F}$ & 66 & 17 & Moderate & $\begin{array}{l}\text { Diarrhoea, } \\
\text { episode } \\
\text { of ileus }\end{array}$ & Severe & $8 \cdot 0$ & 3.9 & $5 \cdot 7$ & 210 \\
\hline 6 & $\mathbf{F}$ & 66 & 5 & Moderate & None & Severe & $13 \cdot 0$ & $3 \cdot 0$ & $5 \cdot 0$ & 205 \\
\hline 7 & $\mathbf{F}$ & 72 & 2 & Moderate & None & Severe & $11 \cdot 2$ & $3 \cdot 7$ & 3.9 & $960+$ \\
\hline 8 & $\mathbf{F}$ & 58 & 2 & Moderate & Diarrhoea & Severe & $11 \cdot 3$ & $3 \cdot 2$ & 1.9 & 300 \\
\hline 9 & $\mathbf{F}$ & 39 & 15 & Mild & None & Mild & $13 \cdot 6$ & 3.6 & $6 \cdot 4$ & 455 \\
\hline 10 & $\mathbf{F}$ & 65 & 7 & Moderate & Diarrhoea & Mild & $11 \cdot 6$ & $3 \cdot 1$ & $6 \cdot 7$ & 240 \\
\hline 11 & $\mathbf{M}$ & 60 & 17 & Mild & None & Mild & $12 \cdot 5$ & $5 \cdot 1$ & $3 \cdot 2$ & 525 \\
\hline 12 & $\mathbf{F}$ & 28 & 0.5 & Moderate & None & Mild & $13 \cdot 0$ & $3 \cdot 4$ & $3 \cdot 8$ & 180 \\
\hline 13 & $\mathbf{F}$ & 60 & 12 & Mild & None & None & $12 \cdot 6$ & $3 \cdot 3$ & $8 \cdot 0$ & 690 \\
\hline 14 & $\mathbf{F}$ & 62 & 15 & Moderate & None & None & $14 \cdot 0$ & $4 \cdot 0$ & $4 \cdot 8$ & 840 \\
\hline 15 & $\mathbf{M}$ & 62 & 20 & Mild & None & None & $11 \cdot 7$ & $5 \cdot 2$ & $5 \cdot 3$ & 255 \\
\hline 16 & $\mathbf{F}$ & 33 & 5 & Severe & None & None & $12 \cdot 5$ & $4 \cdot 8$ & $4 \cdot 4$ & 425 \\
\hline 17 & D & 42 & 12 & Mild & None & None & $13 \cdot 9$ & $4 \cdot 0$ & 3.9 & 410 \\
\hline 18 & $\mathbf{F}$ & 51 & 5 & Severe & None & None & $9 \cdot 2$ & $3 \cdot 0$ & $10 \cdot 8$ & 512 \\
\hline 19 & $\mathbf{F}$ & 62 & 4 & Moderate & Diarrhoea & None & $12 \cdot 8$ & $3 \cdot 8$ & $5 \cdot 0$ & 650 \\
\hline 20 & $\mathbf{F}$ & 72 & 1 & Severe & None & None & $14 \cdot 6$ & $4 \cdot 0$ & $3 \cdot 2$ & 350 \\
\hline 21 & $\mathbf{F}$ & 39 & 3 & Moderate & None & None & $13 \cdot 3$ & 4.0 & 6.8 & 320 \\
\hline
\end{tabular}


venous $\mathrm{Cr}^{51} \mathrm{Cl}$ (Van Tongeren and Majoor, 1966) which labels plasma proteins in vivo.

\section{RESULTS}

CLINICAL FEATURES Seven patients complained of intestinal symptoms: diarrhoea in five, diarrhoea with alternating constipation in one, and constipation alone in one. Two symptomatic patients had had well-documented episodes of ileus, one of whom required laparotomy. The large bowel was not examined in all patients so the part played by large bowel involvement in producing symptoms cannot be assessed. These features are summarized in Table I.

RADIOLOGICAL FEATURES OF SMALL BOWEL INVOLVEMENT Twelve of the 21 patients had radiological evidence of small bowel involvement. Their bowel lumen diameter measurements are shown in Table II. The jejunum was dilated in all 12 patients with radiological evidence of small bowel involvement (Figs.

TA B LE I-continued

CLINICAL FEATURES AND RESULTS OF INTESTINAL FUNCTION STUDIES IN 21 PATIENTS WITH SYSTEMIC SCLEROSIS

\begin{tabular}{|c|c|c|c|c|c|c|c|}
\hline \multicolumn{4}{|l|}{ Absorption } & \multirow{2}{*}{$\begin{array}{l}\text { Figlu } \\
(n=1<17 m g)\end{array}$} & \multirow{2}{*}{$\begin{array}{l}B S P \\
(n=<5 \%)\end{array}$} & \multirow{2}{*}{$\begin{array}{l}\text { Urinary } \\
\text { Indican } \\
(n=48-96 \\
m g / \text { day })\end{array}$} & \multirow[t]{2}{*}{ Histology } \\
\hline $\begin{array}{l}\text { Glucose } \\
\text { Maximum } \\
\text { rise }(m g / 100 \mathrm{ml}, \\
n=>40)\end{array}$ & $\begin{array}{l}\text { Xylose } \\
(n=>5 \mathrm{~g} / \text { with } \\
25 \mathrm{~g} \text { dose })\end{array}$ & $\begin{array}{l}\text { Faecal Fat } \\
(n=<5 \text { g/day })\end{array}$ & $\begin{array}{l}B_{12}+ \\
I . F . \\
(n=>10 \%)\end{array}$ & & & & \\
\hline 25 & $3 \cdot 3$ & $7 \cdot 0$ & $8 \cdot 5$ & 19 & 10 & 169 & - \\
\hline 70 & $3 \cdot 5$ & 4.9 & $10 \cdot 1$ & 42 & 4 & 38 & - \\
\hline 84 & $3 \cdot 4$ & $8 \cdot 3$ & - & 16 & 2 & 29 & Not successful \\
\hline 60 & 1.0 & 8.9 & $3 \cdot 3$ & 34 & 5 & 100 & $\begin{array}{l}\text { Normal jejunal } \\
\text { mucosa }\end{array}$ \\
\hline 20 & - & $33 \cdot 0$ & 0.7 & 14 & 5 & $\begin{array}{l}100 \\
\left(2 \times 10^{6} E . \text { coli }\right. \\
\text { in duodenum })\end{array}$ & - \\
\hline 65 & $2 \cdot 8$ & $3 \cdot 0$ & $17 \cdot 5$ & 42 & 6 & 55 & $\begin{array}{l}\text { Normal fourth } \\
\text { part duodenal } \\
\text { mucosa }\end{array}$ \\
\hline 45 & - & $3 \cdot 0$ & $5 \cdot 4$ & 0 & - & - & 一 \\
\hline 60 & $1 \cdot 6^{1}$ & $7 \cdot 0$ & $10 \cdot 9$ & 0 & - & 51 & - \\
\hline 60 & 3.9 & $2 \cdot 2$ & $12 \cdot 2$ & 16 & 4 & 54 & $\begin{array}{l}\text { Normal jejunal } \\
\text { mucosa }\end{array}$ \\
\hline 85 & $4 \cdot 8$ & $2 \cdot 6$ & $9 \cdot 0$ & 25 & 5 & 75 & $\begin{array}{l}\text { Normal second } \\
\text { part duodenal } \\
\text { mucosa }\end{array}$ \\
\hline 105 & $7 \cdot 3$ & $2 \cdot 5$ & $6 \cdot 5$ & 16 & 5 & 36 & - \\
\hline 76 & $4 \cdot 4$ & 5.5 & - & 26 & 8 & 82 & $\begin{array}{l}\text { Normal third } \\
\text { part duodenal } \\
\text { mucosa }\end{array}$ \\
\hline 25 & 3.0 & $2 \cdot 3$ & $12 \cdot 4$ & 19 & - & 58 & $\begin{array}{l}\text { Normal second } \\
\text { part duodenal } \\
\text { mucosa }\end{array}$ \\
\hline 50 & $2 \cdot 4$ & $3 \cdot 2$ & $5 \cdot 7$ & 15 & 6 & 45 & $\begin{array}{l}\text { Normal jejunal } \\
\text { mucosa }\end{array}$ \\
\hline 54 & $3 \cdot 2$ & $3 \cdot 5$ & $15 \cdot 0$ & 16 & 7 & 58 & - \\
\hline 30 & $3 \cdot 8$ & $2 \cdot 3$ & $5 \cdot 4$ & 26 & 3 & 59 & $\begin{array}{l}\text { Normal second } \\
\text { part duodenal } \\
\text { mucosa }\end{array}$ \\
\hline 65 & 3.9 & $2 \cdot 3$ & $8 \cdot 0$ & 20 & 4 & 44 & $\begin{array}{l}\text { Normal third } \\
\text { part duodenal } \\
\text { mucosa }\end{array}$ \\
\hline 85 & 5.9 & 3.9 & - & 168 & 4 & 90 & - \\
\hline 70 & - & $1 \cdot 4$ & - & 19 & 3 & 51 & - \\
\hline 65 & $3 \cdot 6$ & 1.9 & $10 \cdot 7$ & 64 & 9 & 43 & $\begin{array}{l}\text { Normal jejunal } \\
\text { mucosa }\end{array}$ \\
\hline 55 & 4.9 & $1 \cdot 5$ & 8.9 & 10 & 9 & 66 & $\begin{array}{l}\text { Normal second } \\
\text { part duodenal } \\
\text { mucosa }\end{array}$ \\
\hline
\end{tabular}


T A B L E I I

BOWEL LUMEN DIAMETERS AND ASSOCIATED RADIOLOGICAL ABNORMALITIES IN 12 PATIENTS WITH SYSTEMIC SCLEROSIS AND SMALL BOWEL INVOLVEMENT

\begin{tabular}{|c|c|c|c|c|c|c|}
\hline Patient No. & $\begin{array}{l}\text { Duodenum } \\
\text { (normal } \\
<35 \mathrm{~mm} \text { ) }\end{array}$ & $\begin{array}{l}\text { Jejunum } \\
\text { (normal } \\
<30 \mathrm{~mm} \text { ) }\end{array}$ & $\begin{array}{l}\text { Ileum } \\
\text { (normal } \\
<25 \mathrm{~mm} \text { ) }\end{array}$ & $\begin{array}{l}\text { Transit } \\
\text { Time } \\
\text { (hours) }\end{array}$ & $\begin{array}{l}\text { 'Pseudo- } \\
\text { diverticula' }\end{array}$ & $\begin{array}{l}\text { 'Wire Spring-like' } \\
\text { Appearance }\end{array}$ \\
\hline 1 & 78 & 55 & 45 & 24 & Jejunum & Ileum \\
\hline 2 & 52 & 41 & 27 & 4 & 0 & 0 \\
\hline 3 & 65 & 44 & 26 & 4 & Jejunum & Jejunum \\
\hline 4 & 48 & 51 & 33 & 33 & $\begin{array}{l}\text { Duodenum }{ }^{1} \text { and } \\
\text { jejunum }\end{array}$ & 0 \\
\hline 5 & 39 & 52 & 47 & 5 & 0 & Jejunum \\
\hline 6 & 38 & 47 & 28 & $5 t$ & 0 & 0 \\
\hline 7 & 42 & 46 & 42 & 6 & Jejunum & 0 \\
\hline 8 & 57 & 53 & 31 & $5 \frac{1}{2}$ & 0 & Jejunum \\
\hline 9 & 35 & 34 & 25 & 6 & 0 & Jejunum \\
\hline 10 & 27 & 36 & 36 & 4 & 0 & 0 \\
\hline 11 & 42 & 42 & 33 & 5 & Ileum & 0 \\
\hline 12 & 42 & 37 & 26 & - & 0 & Jejunum \\
\hline
\end{tabular}

3 and 4). The duodenum was dilated in 10 and in these patients the duodenal abnormalities were the most striking feature (Fig. 2). The ileum diameters were above normal in all patients but dilatation was only marked in three. Other abnormalities included thick folds in nine patients, 'pseudo-diverticula', ie, small outpouches with some proximal narrowing simulating a neck formation (Fig. 5) in four patients, and gross typical diverticula in one. In six patients there was a remarkable wire-spring appearance of the thick loops when not distended with barium, an appearance not unlike that seen radiologically in lymphangiectasia and also submucosal haemorrhage (Fig. 4). Stasis did not appear to be a feature except very temporarily and transit times over six hours were seen only in two patients; but appearances of disordered motility were noted-loops lying dilated with barium, then contrast passing quickly on, often through several abnormal loops before becoming arrested in another dilated loop. At times the second part of the duodenum appeared like a sump, contrast unable to pass over the vertebral column, with delay in contrast passing between the second and third parts of the duodenum. Flocculation was seen in seven patients.

Eight patients had radiological abnormalities classed as severe (Table I); of these, three had clinically severe, four moderate, and one mild systemic sclerosis. Of four patients with mild radiological changes, two had moderate and two mild overall disease. Nine patients had no demonstrable small bowel involvement, and of these three each respectively had clinically severe, moderate, and mild systemic sclerosis.

The probable duration of systemic sclerosis in the eight patients with severe radiological changes averaged 7.6 years (range one to 17 years), in the four with mild radiological changes $\mathbf{9 . 8}$ years (range 0.5 to 15 years), and in the nine patients with no radiological changes 8.5 years (range one to 20 years).

NUTRITIONAL STATE Of the eight patients with severe radiological abnormalities only two (nos. 4 and 5) were below their ideal body weight (Table I). Those patients with mild or absent radiological bowel involvement were within their ideal range of body weight.

The mean haemoglobin concentration in the eight patients with severe radiological small bowel involvement was $11.4 \mathrm{~g}$ (range 8 to $13 \mathrm{~g}$ ); in the four with mild lesions it was $12.7 \mathrm{~g}$ (range 11.6 to $13.6 \mathrm{~g}$ ), and in those with no lesion, it was also $12.7 \mathrm{~g}$ (range 9.2 to $14.6 \mathrm{~g}$ ); in those with severe involvement mean serum albumin concentration was $3.5 \mathrm{~g}$ (range 3.0 to $4.5 \mathrm{~g}$ ); those with mild involvement had a mean value of $3.8 \mathrm{~g}$ (range 3.1 to $5.1 \mathrm{~g}$ ), and in those with no involvement it was $4.0 \mathrm{~g}$ (range 3.3 to $5.2 \mathrm{~g}$ ).

The patients with severe radiological small bowel lesions had a mean serum folate level of $4.0 \mathrm{~m} \mu \mathrm{g}$ (range 1.9 to $7.2 \mathrm{~m} \mu \mathrm{g}$ ) and vitamin $B_{12}$ level of 475 $\mu \mu \mathrm{g}$ (range 210 to $960 \mu \mu \mathrm{g}$ ); those with mild lesions had a mean folate level of $5.0 \mathrm{~m} \mu \mathrm{g}(3.2$ to $6.7 \mathrm{~m} \mu \mathrm{g})$ and vitamin $B_{12}$ level of $350 \mu \mu \mathrm{g}(180$ to $525 \mu \mu \mathrm{g})$ and those with no radiological lesions had a mean folate level of $5.8 \mathrm{~m} \mu \mathrm{g}(3.2$ to $10.8 \mathrm{~m} \mu \mathrm{g})$ and vitamin $\mathrm{B}_{12}$ level of $495 \mu \mu \mathrm{g}$ (320 to $\left.840 \mu \mu \mathrm{g}\right)$.

ABSORPTION Faecal fat excretion averaged $9.4 \mathrm{~g} / 24$ hr (range 3.0 to $33.0 \mathrm{~g}$ ) amongst the patients with severe lesions, $3.2 \mathrm{~g} \mathrm{(2.2} \mathrm{to} 5.5 \mathrm{~g})$ amongst those with mild lesions, and $2.5 \mathrm{~g}(1.4$ to $3.9 \mathrm{~g})$ in those with no 


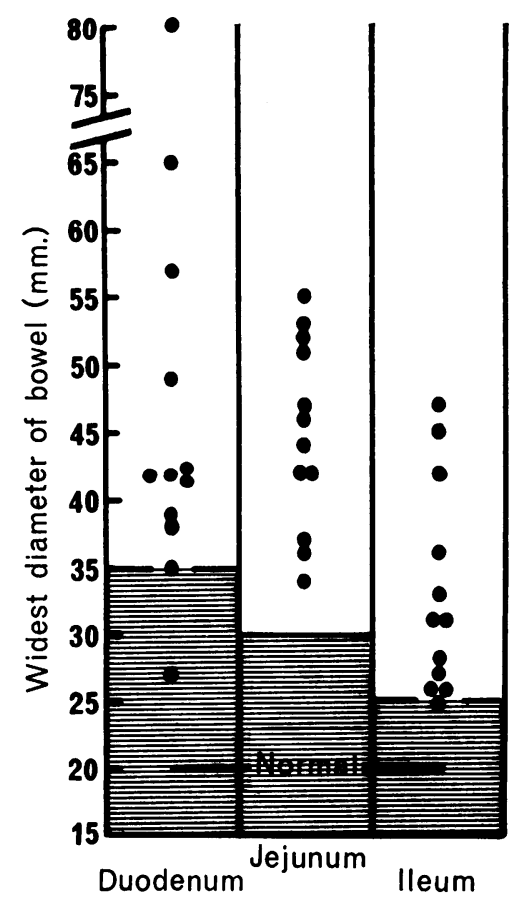

FIG. 2. Bowel lumen diameters in 12 radiologically abnormal patients with systemic sclerosis compared with normal ranges.

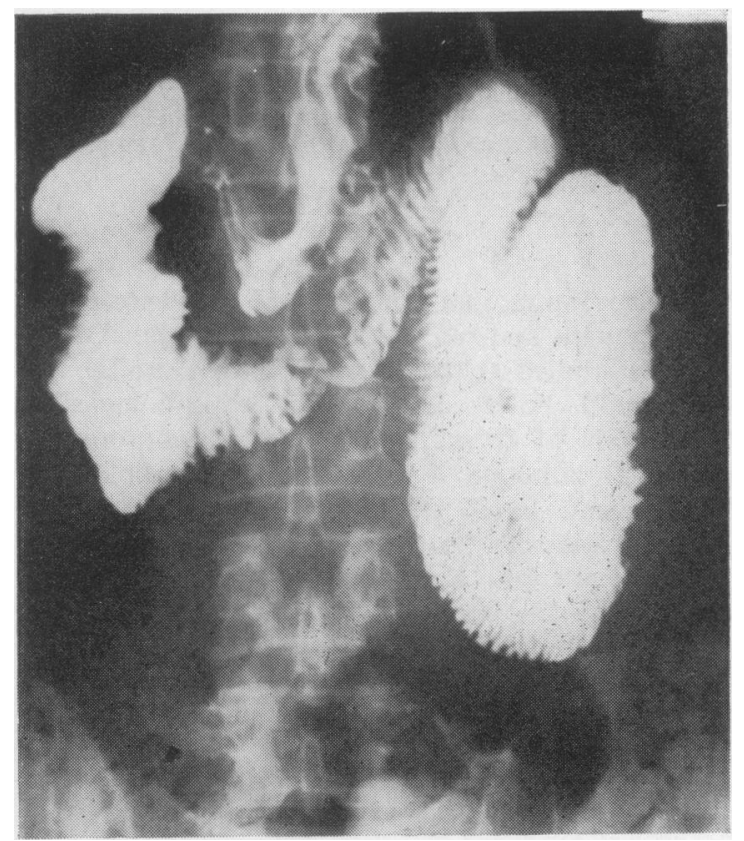

FIG. 4.

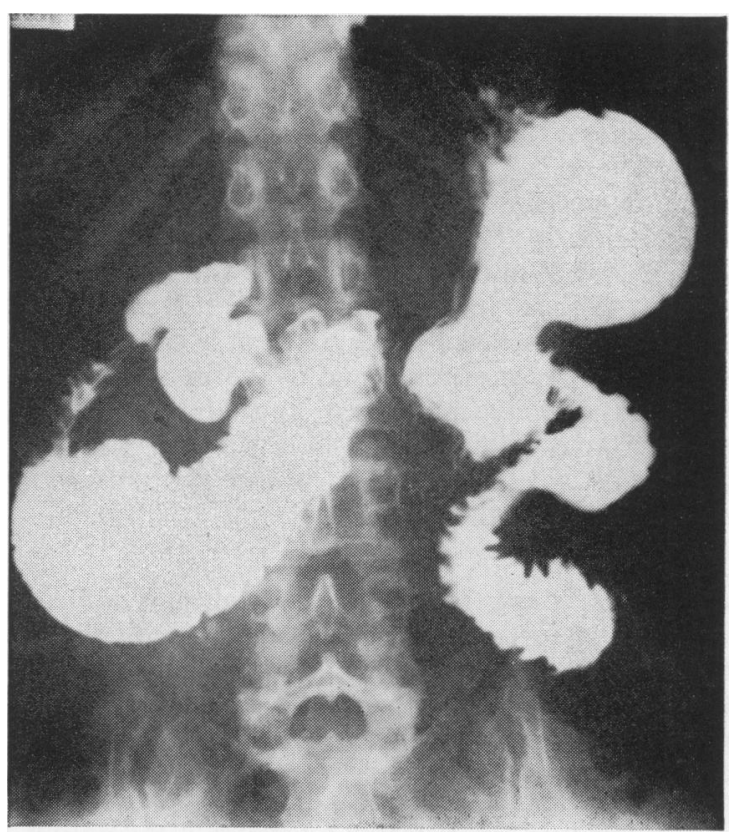

FIG. 3. Normal stomach, first and second parts of duodenal loop but grossly dilated third and fourth parts with a 'sump' effect. The jejunum shows coarse folds and slight dilatation.

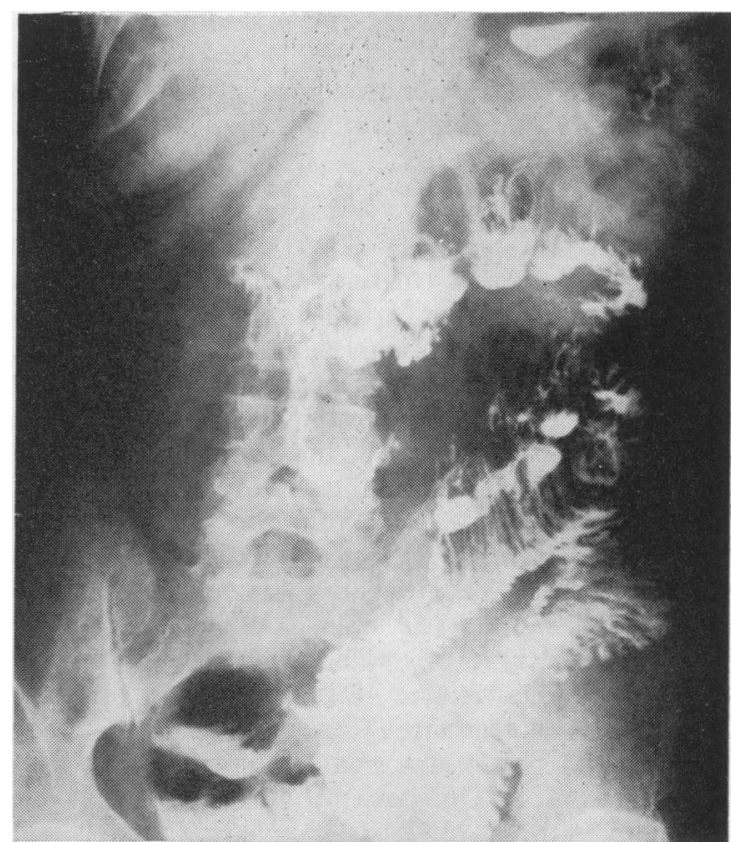

FIG. 5.

FIG. 4. Dilated second and third parts of the duodenum, coarse mucosa in the jejunum and moderate dilatation. Note the relatively undilated duodenum passing over the vertebral column and the wire-spring appearance of thick loops when not distended with barium.

FIG. 5. Erect film showing dilated distal jejunum and fluid levels in the proximal ileum. Note several 'pseudodiverticula' in the middle of the film on the left and accentuated transverse folds in the same region. 
radiological involvement (Table I). Five out of the eight patients with severe radiological lesions had steatorrhoea.

A low rise of blood glucose after an oral load was found in two patients with severe lesions (nos. 1 and 5) and in two patients with no demonstrable lesions (nos. 13 and 16). Significantly low xylose excretion $(<3 \mathrm{~g})$ was seen in two patients with severe lesions (nos. 4 and 6 ) and in one patient with no radiological change (no. 14). Impaired absorption of vitamin $\mathbf{B}_{12}+$ intrinsic factor was present in two patients (nos. 4 and 5), both with severe radiological changes.

ADDITIONAL DATA Raised levels of urinary indican were found in three patients (Table I) with severe radiological changes (nos. 1, 4, and 5). Intubation was only performed in patient 5 and a significant growth $\left(2 \times 10^{6}\right)$ of $E$. coli cultured from her duodenal aspirate.

Raised Figlu excretion following a histidine load was found in 12 patients (four with severe, two with mild, and six with no bowel lesions); there was no relationship between serum folate levels and urinary excretion of Figlu.

Peroral mucosal biopsy was performed in 11 patients (five with radiological abnormalities), from the duodenum in seven, and jejunum in four, and was always normal.

There were no abnormalities of liver function; results of bromsulphalein excretion are shown in Table I.

CORRELATION OF SMALL BOWEL INVOLVEMENT WITH OTHER FEATURES OF THE DISEASE Figure 6 shows the incidence of other manifestations of systemic sclerosis in the 12 patients of the current study with small bowel abnormalities compared with 14 patients (nine from the current study and five from our records) with definite systemic sclerosis but normal barium meal and follow-through radiographs. Both groups were of similar duration of disease and contained patients with gross, moderate, and mild skin sclerosis. Telangiectasia, calcinosis, and Raynaud's phenomenon, with a prolonged reactive hyperaemia, were of similar incidence, as was other systemic involvement. Oesophageal involvement, however, was seen more frequently $(92 \%)$ in patients with small bowel abnormalities compared to those without $(42 \%)$. One patient had severe small bowel disease without obvious oesophageal abnormality on $x$-ray examination. A positive L.E. cell test and the presence of antinuclear factor was of equal incidence in both groups (about 15\% and 80\% respectively).

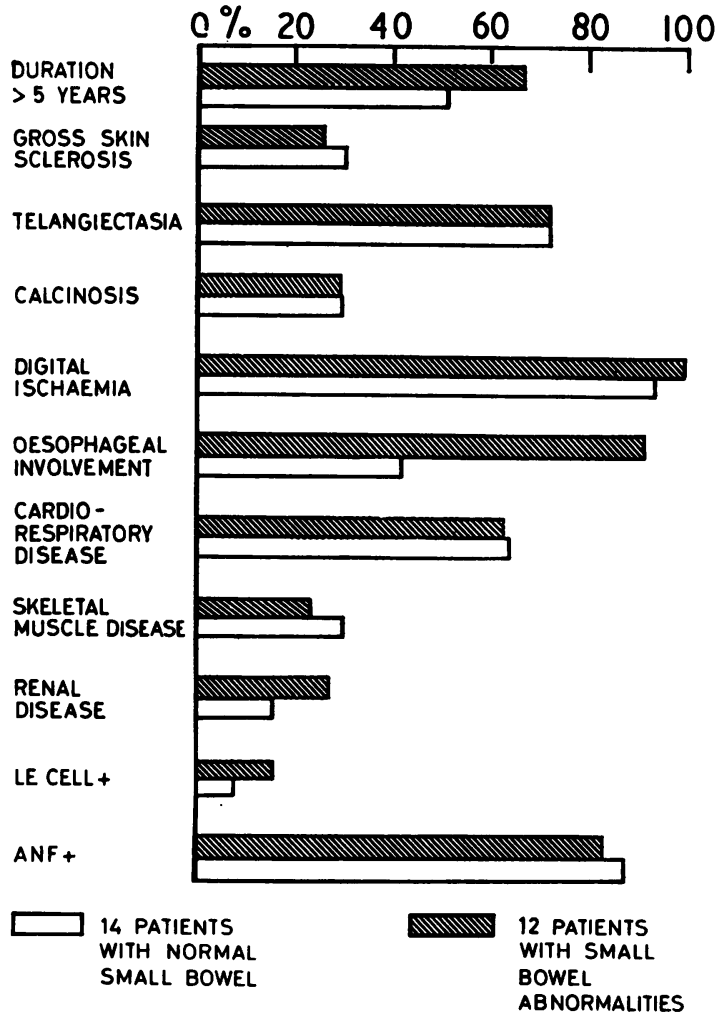

FIG. 6. Systemic sclerosis: 12 with and 14 patients without small bowel involvement suffering from systemic sclerosis correlated with other features of the disease.

\section{DISCUSSION}

We have found that small bowel involvement in patients with systemic sclerosis is common. Of 21 patients studied at the Hammersmith Hospital, 12 had small bowel lesions shown radiologically $(57 \%)$. Six of these patients were asymptomatic (Table I) although three had severe radiological involvement. Small bowel involvement, however, may occasionally be the outstanding feature of systemic sclerosis and two of our patients had episodes of ileus. Orabona and Albano (1958) have drawn attention to the serious nature of this complication and the futility of laparotomy.

The radiological features of small bowel involvement previously reported are thick folds, narrowed lumens, decreased peristalsis, dilated loops, segmentation, and flocculation (Kemp-Harper and Jackson, 1963). Many authors have commented on dilated segments of small intestine, in particular the duodenum and jejunum (Sommerville et al, 1959; Heinz et al, 1963; Sackner, 1966). These reports are 
confirmed by our measurements of bowel diameter (Table II). Our upper limits of normal $(30 \mathrm{~mm}$ for jejunum and $25 \mathrm{~mm}$ for ileum) seemed reasonable in view of the observations by Haworth, Hodson, Joyce, Pringle, Solimano, and Young (1967) and Laws, Shawdon, Booth, and Stewart (1963). Thus diameters well above $30 \mathrm{~mm}$, as in most of our cases, were undoubtedly abnormal. Dilatation of parts of the jejunum and duodenum was common and in some cases marked (Figs. 2, 3, and 4).

Many patients had thickened folds, some with 'wire spring' appearances (simulating lymphangectasia) and pseudo-diverticula (Figs. 4 and 5). No stenoses were seen in our series despite previous reports (Sackner, 1966), and only local abnormalities of motility were seen on screening. As previously noted by Reinhardt and Barry (1962), flocculation of barium was common. We found little correlation between transit time and degree of involvement.

Six of the 12 patients with radiological involvement had steatorrhoea. In one it was severe but in the other five faecal fat was less than $10 \mathrm{~g} /$ day. There have been many case reports of severe steatorrhoea in systemic sclerosis (Kahn et al, 1965; Cliff et al, 1966; Salen et al, 1966; Greenberger et al, 1967) but we consider that more recognition should be given to the mild steatorrhoea commonly found and which requires no treatment.

Carbohydrate absorption was difficult to assess. Although abnormally low maximal rises in blood glucose after an oral glucose load was found in four patients, two with radiological involvement and two without, variation in the rate of stomach emptying affects glucose absorption. Xylose excretion is affected by renal function and there was evidence of renal impairment in two of the three patients (nos. 4 and 6) with low xylose excretion.

Vitamin $\mathbf{B}_{12}+$ intrinsic factor absorption was impaired in two patients (nos. 4 and 5), both of whom had evidence of small bowel bacterial colonization. However, both had normal serum $B_{12}$ levels; both had had Schilling tests in the past.

Only the patient with severe steatorrhoea was obviously malnourished, and one other patient was also below his ideal body weight. However, there was a tendency for those patients with severe radiological small bowel involvement to have lower levels of haemoglobin, serum folate, and serum albumin.

In the series of 21 patients, 12 had raised excretion of Figlu in response to a histidine load; four of these had radiologically severe small bowel involvement. The reason for these alterations in histidine metabolism in systemic sclerosis is not clear, but this dissociation between serum folate levels and urinary excretion of Figlu has recently been described in rheumatoid arthritis by Omer and Mowat (1968), who suggested that there may be deficiency of Figlu transferase, possibly related to activity of the disease.

The mechanism of the malabsorption complicating systemic sclerosis is not clear. Leneman et al (1962) discussed four possible mechanisms; they were bowel wall fibrosis, producing mechanical interference with peristalsis and poor mixing, blocked lymphatics, arteritis, and bacterial colonization.

Fibrosis of the muscular layers of the bowel wall producing disorder of motility and mixing is probably at least partly responsible for the malabsorption in our series, although this is difficult to prove functionally. Actual histological proof of fibrosis is difficult to obtain without laparotomy (we found that peroral mucosal biopsy did not show mucosal fibrosis or excess collagen around Brunner's glands as reported by Hoskins et al, 1962), and although we were unable to obtain specimens on some of the patients with severe bowel lesions, we consider this investigation to be unhelpful in the recognition of small bowel involvement.

Fibrosis of the bowel wall might lead to lymphatic obstruction, and the radiological appearance like lymphangiectasia in six patients may be relevant; but in the two patients in whom gastrointestinal protein loss was assessed we were unable to demonstrate excessive loss into the bowel-a feature of the lymphatic obstruction of congenital lymphangiectasia. Thus the low serum albumin levels seen in some of our patients with small bowel involvement cannot be ascribed to this mechanism.

Although small artery occlusion is a manifestation of systemic sclerosis it does not appear to be any commoner, or more severe in those with small bowel lesions than those without. Thus there was an almost equal incidence and severity of digital artery occlusion, myopathy, and renal disease in both groups of patients (Fig. 6). In addition there were no symptoms suggestive of chronic ischaemia of the small bowel.

Bacterial colonization of the small bowel, producing steatorrhoea, is now a well documentated complication of systemic sclerosis (Kahn et al, 1965; Salen et al, 1966). Wide, hypomotile loops of small bowel provide good sites for bacterial colonization. Four patients also had outpouching or pseudodiverticula, a feature previously noted by Heinz et al (1963). In one patient there were definite diverticula and these may be a natural end stage of the small bowel involvement. Of the six patients with steatorrhoea, three had raised urinary indican excretion, suggesting small bowel bacterial colonization. Although in two the rise was only small and might perhaps be ascribed to creatorrhoea (Fordtran, 
Scroggie, and Polter, 1964) one of these (no. 5) had a significant growth of $E$. coli cultured from her duodenal juice and responded symptomatically to tetracycline.

It would appear that there are some patients with systemic sclerosis and small bowel involvement producing steatorrhoea in whom antibiotic therapy might be beneficial; three of our patients with steatorrhoea had evidence of bacterial colonization, but in the three others there was none.

It is not possible to predict which patients with systemic sclerosis are likely to have small bowel lesions. Gastrointestinal symptoms may be absent, and apart from frequent $(92 \%)$ accompanying oesophageal abnormality the incidence of other systemic involvement in groups with and without small bowel involvement was similar (Fig. 6). Furthermore, even patients with minimal skin or other visceral sclerosis may have severe small bowel abnormalities (Orabona and Albano, 1958; Rodnan and Fennel, 1962) as an early manifestation of systemic sclerosis. Certainly in our series there was little correlation between small bowel involvement and overall severity or duration of systemic sclerosis. Barium follow-through examinations should be done in all patients with systemic sclerosis to detect the frequent small bowel involvement.

\section{SUMMARY}

The structure and function of the small bowel have been studied in 21 patients with systemic sclerosis. Twelve had radiological small bowel involvement; six of these had mild steatorrhoea and two impaired vitamin $B_{12}$ absorption.

The diagnosis of small bowel involvement depends on radiological examination. Dilated loops of duodenum and jejunum are the striking abnormality and best detected by accurately measuring the diameter of the lumen. In addition we found thickened folds, 'pseudodiverticula', wire spring-like appearance, disordered motility, and flocculation.

Possible mechanisms for steatorrhoea in this disease are discussed. Small bowel bacterial colonization seemed a likely explanation in one patient and possible in two.

There was no correlation between duration, severity, or frequency of other organ involvement by systemic sclerosis and small bowel involvement, with the exception of almost invariable oesophageal abnormality in those patients with small bowel disease.

Systemic sclerosis affects the small bowel frequently and often early in the course of the disease; involvement is usually occult.
We gratefully acknowledge the encouragement and advice kindly given by Dr F. H. Doyle, Dr G. Neale, and Dr V. Hoffbrand. We thank Professor E. G. L. Bywaters and $\mathrm{Dr}$ P. J. L. Holt for allowing us to study patients under their care. The duodenal intubation and bacterial culture of small bowel contents in patient no. 5 was kindly performed by $\mathrm{Dr} \mathrm{S}$. Tabaqchali. We thank also $\mathrm{Mr}$ J. Morgan for the measurements of serum $\mathrm{B}_{12}$ and folate levels and urinary Figlu estimations, and Miss S. Patmore for the faecal fat measurements.

\section{REFERENCES}

Abrams, H. L., Carnes, W. H., and Eaton, J. (1954). Alimentary tract in disseminated scleroderma with emphasis on small bowel. Arch. intern. Med., 94, 61-81.

Anderson, B. B. (1964). Investigations into the Euglena method for the assay of the vitamin $B_{12}$ in serum. J. clin. Path., 17, 14-26.

Atkinson, M., and Summerling, M. D. (1966). Oesophageal changes in systemic sclerosis. Gut, 7, 402-408.

Bianchi, F. A., Bistrie, A. R., Wendt, U. E., Puro, H. E., and Keech, M. K. (1966). Analysis of twenty-seven cases of progressive systemic sclerosis (including two with combined systemic lupus erythematosus) and a review of the literature. J. chron. Dis., 19, 953-977.

Case Reports. (1965). Mayo Clin. Proc. 40, 714-730, and New Engl. J. Med., 273, 1210-1219.

Chanarin, I., and Bennett, M. C. (1962). A spectrophotometric method for estimating formimino-glutamic and urocanic acid. Brit. med. J., 1, 27-29.

Clark, M., and Fountain, R. B. (1967). Oesophageal motility in connective tissue disease. Brit. J. Derm., 79, 449-452.

Cliff, I. S., Herber, R., and Dennis, D. J. (1966). Control of malabsorption in scleroderma. J. invest. Derm., 47, 475-483.

Crosby, W. H., and Kugler, H. W. (1957). Intraluminal biopsy of the small intestine. Amer. J. dig. Dis., 2, 236-241.

Crown, S. (1961). Visceral scleroderma without skin involvement. Brit. med. J., 2, 1541-1543.

Curson, G., and Walsh, J. (1962). A method for the determination of urinary indoxyl sulphate (indican). Clin. chim. Acta, 7, 657-663.

Dacie, J. V., and Lewis, S. M. (1963). Practical Haematology, 3rd ed. Churchill, London.

Dawson, J. M. (1968). Unpublished observations.

Drake, A. M., LeFeber, E. J., and Patterson, M. (1964). Collagen disease primarily affecting the gastrointestinal tract. Amer. J. dig. Dis., 9, 872-879.

Fordtran, J. S., Scroggie, W. B., and Polter, D. E. (1964). Colonic absorption of tryptophan metabolites in man. J. Lab. clin. Med., 64, 125-132.

Fountain, R. B., and Nash, A. G. (1967). Systemic sclerosis of the small intestine. Proc. roy. Soc. Med., 60, 1269-1270.

Goetz, R. H., and Berne, M. B. (1945). The pathology of progressive systemic sclerosis (generalized scleroderma) with special reference to changes in the viscera. Clin. Proc., 4, 337-392.

Golden, R. (1959). Radiologic Examination of the Small Intestine, 2nd ed. Thomas, Springfield, Ill.

Goldgraber, M. B., and Kirsner, J. B. (1957). Scleroderma of the gastrointestinal tract. Arch. Path., 64, 255-265.

Greenberger, N. J., Ruppert, R. D., and Tzogournis, M. (1967). Use of medium chain triglycerides in malabsorption. Ann. intern. Med., 66, 727-734.

Hale, C. H., and Schatzki, R. (1944). The roentgenological appearance of the gastrointestinal tract in scleroderma. Amer. J. Roentgenol., 51, 407-420.

Haworth, E. M., Hodson, C. T., Joyce, C. R. B., Pringle, E. M., Solimano, G., and Young, W. F. (1967). Radiological measurement of small bowel calibre in normal subjects according to age. Clin. Radiol., 18, 417-421.

Heinz, E. R., Steinberg, A. J., and Sackner, M. A. (1963). Roentgenographic and pathologic aspects of intestinal scleroderma. Ann. intern. Med., 59, 822-826.

Herrington, J. L., Jr (1959). Scleroderma as a cause of small-bowel obstruction. Arch. Surg., 78, 17-24.

Horswell, R. R., Hargrove, M. D., Jr, Peete, W. P., and Ruffin, J. M. (1961). Scleroderma presenting as the malabsorption syndrome. Gastroenterology, 40, 580-582. 
Hoskins, L. C., Nurris, H. T., Gottlieb, L. S., and Zamcheck, N. (1962). Functional and morphologic alterations of the gastrointestinal tract in progressive systemic sclerosis (scleroderma). Amer. J. Med., 33, 459-470.

Kahn, I. J., Jeffries, G. H., and Sleisenger, M. H. (1965). The effect of antibiotics on the malabsorption of scleroderma. (Abstract). Gastroenterology, 48, 825 .

Van de Kamer, J. H., ten Bokkel Huinink, H., and Weyers, H. A (1949). Rapid method for the determination of fat in feces. J. biol. Chem., 177, 347-355.

Kemp-Harper, R. A., and Jackson, D. C. (1965). Progressive systemic sclerosis. Brit. J. Radiol., 38, 825-834.

Kraus, E. J. (1924). Zur Pathogenese der diffusen sklerodermie. Virchows Arch. path. Anat., 253, 710-734.

Laws, J. W., Shawdon, H., Booth, C. C., and Stewart, J. S. (1963). Correlation of radiological and histological findings in idiopathic steatorrhoea. Brit. med. J., 1, 1311-1314.

Leneman, F., Fierst, S., Gabriel, J. B., and Ingegno, A. P. (1962) Progressive systemic sclerosis of the intestine presenting as malabsorption syndrome. Gastroenterology, 42, 175-180.

Meszaros, W. T. (1958). The regional manifestations of scleroderma. Radiology, 70, 313-325.

McBrien, D. J., and Lockhart-Mummery, H. E. (1962). Steatorrhoea in progressive systemic sclerosis (scleroderma). Brit. med. J., 2, 1653-1656.

Niepel, G., Kostka, D., and Monca, S. (1966). Dysperistalsis of the esophagus in progressive scleroderma, rheumatoid polyarthritis and other connective tissue diseases. (In Slovak). Bratisl. lek. Listy, 46(2), 498-503.

Omer, A., and Mowat, A. G. (1968). Nature of anaemia in rheumatoid arthritis. Ann. rheum. Dis., 27, 214.

Orabona, M. L., and Albano, O. (1958). Progressive systemic sclerosis. Acta med. scand., suppl., 333.

Reinhardt, J. F., and Barry, W. F., Jr (1962). Scleroderma of the small bowel. Amer. J. Roentgenol., 88, 687-692.

Rodnan, G. P. (1966). In Modern Trends in Rheumatology I. Edited by A. G. S. Hill. Butterworths, London.
- and Fennell, R. H., Jr (1962). Progressive systemic sclerosis sine scleroderma. J. Amer. med. Ass., 180, 665-670.

Rosenthal, F. D. (1957). Small intestinal lesions with steatorrhea in diffuse systemic sclerosis (scleroderma). Gastroenterology, 32, 332-342.

Rosson, R. S., and Yesner, R. (1965). Peroral duodenal biopsy in progressive systemic sclerosis. New Engl. J. Med., 272, 391-394.

Sackner, M. A. (1966). Scleroderma. Grune and Stratton, New York and London.

Saladin, T. A., French, A. B., Zarafonetis, C. J. D., and Pollard, H. M. (1966). Esophageal motor abnormalities in scleroderma and related diseases. Amer. J. dig. Dis., 11, 522-535.

Salen, G., Goldstein, F., and Wirts, C. W. (1966). Malabsorption in intestinal scleroderma. Relation to bacterial flora and treatment with antibiotics. Ann. intern. Med., 64, 834-841.

Schilling, R. F. (1953). Intrinsic factor studies. II. The effect of gastric juice on the urinary excretion of radioactivity after the oral administration of radioactive vitamin $\mathbf{B}_{12}$. J. Lab. clin. Med., 42, 860-866.

Sommerville, R. L., Bargen, J. A., and Pugh, D. G. (1959). Scleroderma of the small intestine. Postgrad. Med., 26, 356-364.

Sonneveldt, H. A., van Leeuwen, P., and Blom, P. S. (1962). Malabsorption in acrosclerosis. Acta med. scand., 171, 391-396.

Van Tongeren, J. H. M., and Majoor, C. L. H. (1966). Demonstration of protein-losing gastroenteropathy: the disappearance rate of ${ }^{51} \mathrm{Cr}$ from plasma and the binding of ${ }^{51} \mathrm{Cr}$ to different serum proteins. Clin. chim. Acta, 14, 31-41.

Treacy, W. L., Baggenstoss, A. H., Slocumb, C. H., and Code, C. F. (1963). Scleroderma of the esophagus. Ann. intern. Med., 59, 351-356.

Tuffanelli, D. L., and Winkelmann, R. K. (1961). Systemic scleroderma. Arch. Derm. (Chic.), 84, 359-371.

Walters, A. H., and Mollins, D. L. (1961). Studies on the folic acid activity of human serum. J. clin. Path., 14, 335-344.

Wooton, I. D. P. (1964). Micro-analysis in Medical Biochemistry, 4th ed. Churchill, London. 